\title{
TINJAUAN HUKUM ISLAM TERHADAP SISTEM KEMITRAAN BAGI HASIL DARI LAHAN PLASMA SAWIT
}

\author{
Ramadhani Alfin Habibie \\ Universitas Islam Negeri Maulana Malik Ibrahim Malang \\ Email:ramadhani_alfin@yahoo.com
}

Abstract

The profit sharing agreement is a binding contract. Plasma Land as the agreement object involves threeparties, they are PT. Bumitama Gunajay a Abadi as the manager Mitra Behaum Cooperative as the bridge between community and company distributing oil palm monthly, and society as the owners of plasma land provided by local government. The grant of plasma land from local government that has no assurance becomes this study object. Types of profit sharing agreement for agricultural or farm products in Islamic law are: musaqah, muzara'ah and mukhabarah. The study discusses whether the profit sharing of oil palm includes in either one of the systems or creates new case in farm's profit sharing. The researcher believes that further research should be done answering this problem. The result shows that the agreement used tends to be mukhabarah, that is a cooperation between land manager and owner in agriculture or farm. However, we cannot say the agreement is appropriate for some aspects. In its practice, it imperfect is that there is no exact location or assurance of the land. Next, in term of sharing profit, they already set clear share in percentage which is in line (not gharar) with the requirements of mukhabarah.

Akad bagi hasil merupakan akad kerjasama yang bersifat mengikat. Lahan Plasma sebagai objek dari akad melibatkan tiga pihak didalamnya yaitu PT. Bumitama Gunajaya Abadi (BGA), Koperasi Mitra Behaum, serta masyarakat selaku pemilik lahan plasma yang diberikan oleh Pemerintah Daerah (Pemda). Pemberian lahan plasma dari pemda yang tidak memiliki kepastian letak inilah yang menjadi objek penelitian. Akad kerjasama bagi hasil pertanian atau perkebunan dalam bukum Islam adalah dalam bentuk musaqah, muzara'ah dan mukhabarah. Persoalan yang muncul adalah apakah bagi hasil dalam perkebunan sawit tersebut termasuk dari 
salah satu dari sistem bagi hasil tersebut ataukah menimbulkan persoalan baru dalam bagi hasil perkebunan. Hasil penelitian adalah kerjasama perkebunan sawit dapat dimasukkan dalam akad mukhabarah yaitu bentuk kerjasama antara pengelola kebun dan pemilik lahan. Beberapa rukun dan syarat sebagian telah terpenubi, namun ada salah satu syarat yang belum terpenubi yaitu pada tanah yang akan ditanami tidak memiliki kepastian letak. Ketidakpastian ini yang menyebabkan kurang sempurnanya syarat mukhabarah.

Keywords: Plasma Field, Profit Sharing, Islamic Law Review

\section{Pendahuluan}

Peraturan Menteri Pertanian No. 98 Tahun 2013 tentang Pedoman Perizinan Usaha Perkebunan disebutkan bahwa bagi perusahaan yang membuka lahan sawit 250 hektar atau lebih maka wajib memfasilitasi pembangunan kebun masyarakat paling sedikit 20\%. Dengan ketentuan tersebut maka jelaslah bahwa lahan sawit yang ada di suatu wilayah tidak hanya dimiliki oleh perusahaan akan tetapi harus bekerjasama dengan masyarakat sekitar kebun tersebut. Penerapan kerjasama seperti inilah yang dinamakan dengan sistem kerjasama plasma sawit, yang mana koperasi bertugas sebagai suatu badan usaha yang dilindungi oleh hukum yang menjembatani antara masyarakat dan perusahaan itu sendiri.

Usaha Perkebunan di Kecamatan Kotawaringin Lama ada 3 jenis usaha, yaitu: Pertama, kebun inti yang perkebunan sawit yang dimiliki oleh perusahaan dan dalam hal pengelolaan dan hasil sepenuhnya milik perusahaan. Kedua, Perkebunan Plasma yaitu merupakan salah satu program pemerintah daerah yang biasa dikenal dengan istilah land reform (pembaharuan lahan) yang mana pemberian lahan kosong kepada masyarakat didaerah tersebut agar dimanfaatkan sebaik-baiknya dan menjadi hak milik warga. Dalam hal ini bekerjasama dengan perusahaan PT. Bumitama Gunajaya Abadi atau disingkat BGA selaku pengelola lahan tersebut. Untuk memudahkan komunikasi dan hubungan kerja dengan masyarakat, maka kegiatan ini dijembatani oleh sebuah koperasi yang bernama Mitra Behaum yang ada di daerah tersebut. Ketiga, kebun sawit milik masyarakat sekitar yang dikelola sendiri oleh para petani.

Fokus dalam penelitian kali ini adalah mengenai perkebunan plasma, setelah melewati beberapa tahapan maka masyarakat akan mendapatkan kompensasi dari Pemerintah Daerah (Pemda) yaitu berupa pemberian lahan sebagai salah satu program pemerintah, namun masyarakat tidak mengetahui letak pasti lahan kepemilikan mereka, akan tetapi mereka tetap mendapatkan pembagian hasil kebun dari lahan plasma sawit tersebut yang dibagikan oleh pihak koperasi setiap 
bulannya. Ketidak jelasan lahan plasma sawit inilah berdampak pada ketidak jelasan bagi hasil yang merupakan bagian yang harus dikaji.

Akad bagi hasil merupakan akad kerjasama yang bersifat mengikat, walaupun hubungan kerja yang terjalin hanyalah janji biasa, namun kedua belah pihak yang terikat perjanjian kerjasama harus mematuhi aturan yang sudah ditetapkan sebelumnya. ${ }^{1}$ Lahan sawit atas nama masyarakat itu arealnya diketahui oleh koperasi, namun secara perorangan letak pastinya belum diketahui secara orang perorang. Masyarakat sebagai pemilik lahan mengetahui bahwa mereka memiliki lahan sawit dibuktikan dengan keanggotaan koperasi dan kartu kepemilikan lahan. Pengelolaan lahan termasuk penanaman dan pemeliharaan kebun sawit dilakukan oleh perusahaan sebagai pemilik modal.

Sekitar 3 (tiga) sampai 5 (lima) tahun sawit sudah mulai berbuah. Pada saat panen masyarakat yang memegang kartu pemilik sawit mendapatkan bagian bagi hasil dari Sisa Hasil Kebun (SHK). Masyarakat yang menjadi anggota koperasi menerima hasil pembagian perkebunan sawit setiap bulan, walaupun mereka tidak mengetahui dengan pasti letak lahan perkebunan tersebut, bagaimana penanaman dan pemeliharaannya. Setelah mendapatkan hasil panen pihak perusahaan menyampaikan kepada koperasi keuntungan bersih yang diperoleh oleh anggota koperasi dan sudah dipotong biaya lainnya. Dengan demikian maka koperasi lah yang membagi hasil perkebunan sawit tersebut kepada masyarakat. Selama ini masyarakat tidak pernah berupaya untuk mengetahui berapa hasil kebun yang dia miliki dan berapa banyak yang harus dia terima dari perusahaan melalui koperasi, namun yang jelas semua anggota koperasi mendapat pembagian yang sama dari hasil lahan plasma sawit.

Dalam pembagian hasil perkebunan tersebut seyogyanya lahan yang menghasilkan lebih banyak seharusnya mendapatkan pembagian yang lebih banyak pula, akan tetapi dalam pengelolaan lahan plasma sawit tidak diketahui lahan milik siapa, yang memiliki hasil banyak dan lahan siapa yang memiliki hasil yang sedikit tapi semuanya dibagi rata. Letak lahan perkebunan sawit tidak pernah mereka ketahui secara pasti hingga beberapa tahun mereka mendapatkan pembagian hasil dengan bermodalkan kartu anggota atau tanda kepemilikan lahan sawit yang diberikan oleh pihak koperasi.

Lahan perkebunan sawit yang diserahkan oleh Pemerintah melewati koperasi sebagai mitra perusahaan pengelola perkebunan sawit tidak pernah diketahui letaknya oleh masyarakat (anggota koperasi). Hal ini memunculkan suatu pertanyaan, apakah bisa dikatakan lahan tersebut milik masyarakat? Apakah ini

1 M. Ali Hasan, Berbagai Macam Transaksi dalam Islam (Jakarta: PT. Raja Grafindo Persada, 2003). h. 271. 
bisa dikatakan sebagai usaha bersama dan bagaimana sistem bagi hasil yang dikelola oleh koperasi dari perkebunan sawit yang dilakukan dengan sistem plasma? Oleh karena itu, maka tidak dapat diketahui pula secara pasti berapa banyak hasil panen dari lahan plasma sawit yang dia miliki. Ketidak jelasan kafling (luas) lahan sawit yang berdampak pada ketidakjelasan hasil inilah yang merupakan bagian yang harus dikaji. Apakah sistem pembagian yang dilakukan oleh koperasi tersebut sudah sesuai dengan hukum Islam? Bagaimana menurut tinjauan Islam dengan model kerjasama dan bagi hasilnya tersebut?

Adapaun penelitian dari Iglesias Asik ${ }^{2}$ menyimpulkan bahwa hubungan kemitraan antara perusahaan dengan masyarakatnya masih kurang baik, hal tersebut dapat dilihat dari banyaknya pernyataan warga (masyarakat Kampung Besiq) yang masih belum memahami apa itu kebun plasma dan pola kerjasama kemitraan serta masyarakat merasa terbebani karena harus menanggung sendiri biaya pengelolaan kebun plasma. Hal serupa juga terjadi di kepulauan Riau berdasarkan penelitian dari Almasdi Syahza, ${ }^{3}$ namun dalam penelitiannya masalah yang dihadapi oleh petani kelapa sawit adalah adanya distorsi harga tandan buah segar (TBS) antara petani plasma dengan petani swadaya. Hal tersebut tentunya selaras dengan paham peneliti bahwa masih banyak terdapat kerancuan dalam sistem kemitraan perkebunan plasma sawit yang menarik unuk dikaji kembali, terutama dari segi kebolehannya dalam hukum Islam mengingat para pelaku usaha yang mayoritas beragama Islam. Terlepas dari hukum Islam dalam bernegara tentunya kita harus mentaati hukum positif yang ada, terkait hal tersebut Rudianto Salmon Sinaga ${ }^{4}$ dalam penelitiannya melihat banyak terjadi kecurangan yang dilakukan perusahaan. Notaris dalam melakukan proses pembuatan akta sebaiknya tidak hanya sekedar mengkonstatir keinginan para pihak, namun juga harus memperhatikan kepentingan pihak-ihak yang dianggap lemas.

Kemudian ada tiga macam akad dalam kerjasama bagi hasil dari pertanian atau perkebunan menurut pendapat jumhur ulama, yaitu: musaqah, muzara'ah dan mukhabarah. Apakah akad bagi hasil dalam perkebunan plasma sawit tersebut termasuk dari salah satu dari diantaranya ataukah menimbulkan persoalan baru

2 Iglesias Asik, "Program Plasma Perkebunan Kelapa Sawit PT. Rimba Rayatama Jaya Dalam Pola Kemitraaan Masyrakat Di Kampung Besiq Kecamatan Damai Kabupaten Kutai Barat," eJournal Ilmu Pemerintahan, No. 2, Vol. 5 (2017).

3 Almasdi Syahza, "Pemberdayaan Ekonomi Masyarakat Pedesaan Melalui Pengembangan Industri Hilir Berbasis Kelapa Sawit Di Daerah Riau," Jurnal Sosiobumaniora, No. 3, Vol. 6 (2004).

4 Rudianto Salmon Sinaga, "Masalah Hukum Dalam Perjanjian Kemitraan Inti Plasma Perkebunan Kelapa Sawit (Studi Kasus Pada PT. SHM dengan Koperasi PGH) dan Tindakan Notaris dalam Menghadapi Perjanjian Kemitraan Inti Plasma Dalam Perkebunan Kelapa Sawit”' (Tesis, Universitas Indonesia, 2011). 
dalam bagi hasil perkebunan? Adapun dalam penelitian Rahmat Indra Irawan ${ }^{5}$ dapat ditarik kesimpulan dalam pembagian hasil antara pemilik kebun dan buruh di Desa Muara Jaya sudah sesuai dengan sebab pembagian hasil dilakukan dengan menyebut persentase bagian dengan jelas, adil dan tidak ada unsur gharar serta hal tersebut berdasarkan apa yang tertulis dalam kompilasi hukum ekonomi syari'ah (KHES), pada BAB IX bagian kedua Rukun dan Syarat Pasal 269. Sistem pengelolaan sawit dan bagi hasil perkebunan sawit sebagaimana yang terjadi di Desa Muara Jaya apakah ini juga terjadi pada masyarakat yang ada di Kecamatan Kotawaringin Lama Kabupaten Kotawaringin Barat Kalimantan Tengah? Pada kecamatan ini salah satu koperasi yang ada adalah koperasi Mitra Behaum yang bermitra dengan PT. Bumitama Gunajaya Abadi. Bagi hasil perkebunan kelapa sawit tersebut dilakukan oleh koperasi Mitra Behaum, yang dapat menimbulkan berbagai macam kontrak (akad). Hal inilah yang perlu dikaji dan dianalisis menurut tinjauan hukum Islam.

Beranjak dari permasalahan tersebut dan dengan keberagamaan penelitian terdahulu, kiranya perlu dilakukan penelitian lebih jauh tentang tinjauan hukum Islam terhadap bagi hasil lahan plasma sawit. Sistem pembagian seperti ini berlaku di hampir semua perkebunan sawit, namun untuk keperluan penelitian ini, peneliti mengambil suatu kasus yang terjadi di Kecamatan Kotawaringin Lama Kabupaten Kotawaringin Barat Kalimantan Tengah yaitu pembagian hasil lahan plasma sawit yang dilakukan oleh koperasi Mitra Behaum. Penelitian kali ini bertujuan untuk mengetahui sistem bagi hasil pada lahan plasma sawit yang diterapkan selama ini serta untuk menggali lebih dalam mengenai hukum Islam terkait bagi hasil serta akad yang digunakan dalam pengelolaan pada lahan plasma sawit yang diterapkan selama ini.

\section{Metode Penelitian}

Jenis penelitian ini adalah penelitian yuridis empiris (field reseach). Penelitian kali ini untuk menilai program-program seperti kontrak yang dilakukan oleh Koperasi Mitra Behaum yang mewakili masyarakat dengan PT. BGA, deskriptifnya itu pemaparan apa yang dimaksud oleh suatu teks dengan cara memfrasekan dengan bahasa peneliti. Sehingga dari penelitian tersebut dapat menggambarkan secara sistematis, faktual, dan akurat mengenai fakta-fakta dan sifat-sifat populasi atau

5 Rahmat Indra Irawan, "Perjanjian Bagi Hasil Antara Buruh Sawit Dan Pemilik Kebun Sawit (Di Desa Muara Jaya Sp3 Kecamatan Kepenuhan Hulu Kabupaten Rokan Hulu Provinsi Riau Perspektif Kompilasi Hukum Ekonomi Syariah)" (Skripsi, Universitas Islam Negeri Maulana Malik Ibrahim, 2016). 
daerah dari objek kajian tersebut. ${ }^{6}$ Penelitian deskriptif bertujuan menggambarkan secara tepat sifat-sifat suatu individu, keadaan, gejala atau kelompok tertentu, atau untuk menentukan penyebaran suatu gejala, atau untuk menentukan ada tidaknya hubungan antara suatu gejala dengan gejala lain dalam masyarakat, ${ }^{7}$ yang berada dalam wilayah kecamatan Kotawaringin Lama.

Jenis pendekatan penelitian ini adalah conceptual approach atau pendekatan konseptual yang artinya beranjak dari pandangan-pandangan dan doktrin-doktrin yang berkembang di dalam ilmu hukum. ${ }^{8}$ Pemahaman akan pandangan-pandangan dan doktrin-doktrin tersebut merupakan sandaran bagi peneliti dalam membangun suatu argumentasi hukum dalam memecahkan isu yang dihadapi. ${ }^{9}$ Pendekatan ini digunakan terhadap data yang diperoleh dari hasil wawancara dengan ketua dan pengelola Koperasi Sawit Mitra Behaum serta masyarakat yang bersangkutan di daerah Kabupaten Kotawaringin Barat Pangkalanbun Provinsi Kalimantan Tengah.

Sumber data utama dalam penelitian kualitatif ialah kata-kata, dan tindakan selebihnya adalah data tambahan seperti dokumen dan lain-lain. ${ }^{10}$ Data yang di pergunakan peneliti dibagi menjadi dua bagian, yakni: Pertama, data primer berupa wawancara dari narasumber yaitu ketua dan pengelola Koperasi Sawit Mitra Behaum serta masyarakat yang menjadi anggota koperasi. Karena data primer adalah sumber utama yang diperoleh langsung dari sumber pertama. ${ }^{11}$ Maka narasumber diatas yang dianggap mengetahui objek dalam penelitian ini. Kedua, adapun data sekunder yang dijadikan peneliti sebagai bahan rujukan ialah literatur- literatur lain seperti al-Qur'an dan Hadits, buku - buku, dan lain lain yang berkaitan dengan menjadi pendukung dalam menganalisis hasil penelitian.

Metode yang digunakan untuk proses pengumpulan data dalam penelitian ini ada tiga langkah, yaitu: Pertama, wawancara adalah percakapan dengan maksud tertentu. Percakapan itu dilakukan oleh dua pihak, yaitu pewawancara (peneliti) yang mengajukan pertanyaan dari yang diwawancarai (ketua, pengelola, serta anggota koperasi Mitra Behaum) yang memberikan jawaban atas pertanyaannya itu. ${ }^{12}$ Kedua, dokumentasi berupa data yang berkaitan dengan keadaan koperasi Mitra Behaum yaitu tentang perjanjian, $M o U$ (nota kesepahaman), kepengurusan dan usaha koperasi tersebut, serta lahan perkebunan sawit yang menyangkut kebun

6 Sumadi Suyabrata, Metode Penelitian (Jakarta: PT. Raja Grafindo Persada, 2003). h. 75.

7 Amiruddin dan Zainal Asikin, Pengantar Metode Penelitian Hukum (Jakarta: PT. Raja Grafindo Persada, 2008).

8 Suharsimi Arikunto, Prosedur Penelitian Suatu Pendekatan Praktek (Jakarta: Rineka Cipta, 2002). h. 23.

9 Peter Mahmud Marzuki, Penelitian Hukum (Jakarta: Kencana, 2011). h. 95.

10 Lexy J. Moeleong, Metode Penelitian Kualitatif (Bandung: Remaja Rosdakarya, 2013). h. 112.

11 Soerjono Soekanto, Pengantar Penelitian Hukum (Jakarta: UI-Press, 2012). h. 12.

12 Lexy J. Moeleong, Metode Penelitian Kualitatif..., h. 135. 
plasma sawit, jumlah dan persyaratan keanggotaan, pembagian hasil sawit dan berbagai hal yang berkaitan dengan hal tersebut. Ketiga, observasi/pengamatan yang dilakukan dengan cara mencari yang berkaitan dengan keadaan desa dan kehidupan masyarakat di lokasi penelitian, Koperasi Mitra Behaum, serta keadaan kebun sawit. Hal tersebut karena merupakan bagian dari cara pengamatan/observasi dan pencatatan secara sistematis terhadap fenomena yang menjadi objek kajian. ${ }^{13}$

\section{Pembahasan}

\section{Bentuk Perjanjian Pada Sistem Bagi Hasil Lahan Plasma Sawit}

Lahan sawit areal terpola plasma adalah $10.138,42$ ha yang terdiri dari 5.069,21 ha dengan pola "Perkebunan Inti", dan 5.069,21 ha dengan pola "Perkebunan Plasma”. Perkebunan inti adalah kebun lahan sawit yang dimiliki oleh perusahaan, dalam hal ini lahan perkebunan milik PT. Bumitama Gunajaya Abadi (BGA) atau dengan kata lain PT. BGA mendapatkan izin untuk menggunakan lahan yang berada di kecamatan tersebut untuk digunakan sebagai lahan perkebunan sawit atau biasa dikenal dengan HGU (Hak Guna Usaha).Sedangkan perkebunan atau lahan plasma adalah lahan tidur (yang belum dimanfaatkan untuk perkebunan) yang mana lahan tersebut diberikan oleh Pemerintah Daerah (Pemda) kepada masyarakat sekitar sebagai konpensasi dari program pemerintah daerah pemda untuk digunakan sebagai lahan perkebunan kelapa sawit. Lahan yang diperuntukan untuk masyarakat, yang dikelola perusa haan inilah yang disebut dengan lahan plasma sawit.

Dalam hal penanaman, secara keseluruhan lahan kelapa sawit tersebut berada dalam dua tahap. Tahap pertama pada tahun 2004 dan tahap kedua pada tahun 2008. Sejak tahun 2005 perusahaan sebagai pengelola lahan kepada sawit tersebut sudah memulai mengadakan penanaman. Masa tanam dilakukan secara bertahap, sehingga setiap tahun selalu ada penanaman dengan jumlah areal yang sudah ditentukan oleh perusahaan sesuai data yang diperoleh dari pihak koperasi.

Untuk memahami sistem bagi hasil pada lahan plasma sawit di koperasi Mitra Behaum, maka ada 3 komponen inti yang harus diuraikan berkaitan dengan fungsi dan tugas masing-masing komponen, sebagai berikut: Pertama, perusahaan sebagai Pengelola Lahan Kelapa Sawit, dalam hal ini PT. BGA berperan besar dalam berjalannya kinerja perkebunanan kelapa sawit baik dari lahan inti maupun lahan plasma. PT. BGA sebagai pemodal utama sekaligus pengelola yang memiliki lahan inti, sebagai pengelola tugas utama dari PT. BGA adalah mengelola lahan

13 Andi Prastowo, Metode Penelitian Kualitatif dalam Perspektif Rancangan Penelitian (Yogyakarta: Ar-Ruzz Media, 2011). h. 205. 
tersebut sejak pengolahan lahan, penanaman, pemeliharaan, sampai panen dan penjualan hasil kebun sawit.

PT. BGA selaku pengelola yang mengkoordinir lahan masyarakat tersebut dalam membiayai perkebunan lahan kelapa sawit, sejak penanaman dan pemeliharaannya mendapatkan pinjaman dari beberapa bank yang ada didaerah tersebut yang selanjutnya apabila sudah panen akan dibayarkan oleh perusahaan kepada bank yang memberikan pinjaman permodalan pengelolaan lahan sawit. Untuk memudahkan dalam pembagian SHK (Sisa Hasil Kebun) pada setiap bulannya PT. BGA bekerjasama dengan koperasi Mitra Behaum dalam hal pembagian hasil kebun sawit. Kedua, koperasi yang bernama koperasi Mitra Behaum mempunyai peran yang sangat penting dalam memfalitasi antara PT. BGA dengan masyarakat yang mendapatkan plasma sawit.Koperasi sebagai jembatan antara masyarakat dan PT. BGA, karena pada kasus penelitian kali ini dari tahap pendaftaran sampai tahap penerimaan lahan plasma serta pembagian hasil kebun atau SHK setiap bulannya semua ditangani oleh pihak koperasi tersebut. Ada beberapa proses dari pandaftaran sampai dengan penerimaannya. Sebagaimana yang diutarakan oleh ketua koperasi Mitra Behaum: ${ }^{14}$

"Ada beberapa tahapan yang harus dilalui apabila ingin mendapatkan lahan konpensasi dari pemerintah daerah, mulai dari pendaftaran dengan memenubi beberapa persyaratan diantaranya: minimal 1 tahun berdomisili dikecamatan kotawaringin lama, umur minimal 17 tabun, KTP penduduk asli setempat, dan harus berkeluarga, serta per KK (kepala keluarga) hanya mendapatkan 1 kali lahan plasma sawit".

Didalam pengelolaan lahan plasma sawit ada pihak yang bertugas membantu pihak koperasi Mitra Behaum dalam penimbangan hasil kebun plasma sawit yang disebut dengan TPK (Tenaga Pengawas Kebun),kebun plasma sawit dari ke 4 daerah tersebut masing-masing memilik TPK nya sendiri-sendiri, jadi di koperasi Mitra Behaum memiliki 4TPK yang bekerja sama pula dengan PT.BGA berkaitan dengan pemeliharaan dan panen. Ketiga, masyarakat selaku anggota koperasi Mitra Behaum, perlu digaris bawahi bahwa yang mendapatkan konpensai adalah warga yang berada diwilayah masyarakat yang berada di empat daerah yaitu: Kelurahan Kotawaringin Hilir (Kohil), Kelurahan Kotawaringin Hulu (Kohul), Desa Sakabulin, dan desa Lalang. Masyarakat di 4 kelurahan/desa yang memenuhi syarat untuk mendapatkan lahan plasma sawit otomatis menjadi anggota koperasi. Anggota koperasi sebagai pemilik lahan yang dibuktikan dengan pemegang kartu anggota koperasi akan mendapatkan pembagian SHK setiap bulannya yang dilakukan 
pihak koperasi Mitra Behaum setelah kebun tersebut sampai masa panennya. Anggota koperasi ini erat kaitannya dengan PT. BGA karena mereka memiliki hak atas lahan plasma tersebut sebagai awal untuk pengembangan perkebunan lahan plasma sawit. Sehingga dalam kasus ini anggota koperasi bisa dikategorikan pula sebagai pemodal yang mana mereka memilik hak atas lahan plasma tersebut.

Setelah melalui prosedur sebagaimana yang dikatakan oleh Masyakin (Ketua Koperasi Sawit) maka tinggal menunggu giliran untuk mendapatkan lahan plasma sawit sebagai konpensasi dari pemerintah daerah. Setelah diumumkannya siapa saja masyarakat yang mendapatkan lahan plasma sawit. Bagi masyarakat yang telah mendapatkan lahan plasma maka mereka akan mendapakan buku merah sebagai bukti kepemilikan lahan yang nantinya digunakan sebagai pengambilan SHK setiap bulannya.Untuk mendapatkan bagi hasil proses menunggu hasil panen sekitar 3-5 tahun seperti penjelasan dari Masyakin: ${ }^{15}$

"Dalam MoUtusebenarnya 3-5 itu sudah berbuah, naa jadi 3-5 tabun tu dinamakan masa tenggang yang dikenal dengan istilah TBM (Tanaman Belum Maksimal), dalam 2 tahun itu masuk dalam masa tenggang dan menghasilkan tetapi tidak masuk masa plasma klo disini masyarakat mengenalnya buah pasir".

Jadi selama proses beberapa tahun tersebut masyarakat belum menerima pembagian hasil dari lahan plasma tersebut. Namun, ada beberapa oknum dari masyarakat sendiri yang setelah menerima pemberian lahan tersebut mereka menjualnya kembali kepada orang yang ingin membelinya baik dari kecamatan yang berbeda maupun dari masyarakat di luar kecamatan tersebut yang ingin membelinya. Penjualan ini dikarenakan warga tersebut tidak ingin menunggu proses TBM serta keinginan mereka untuk mendapatkan uang tunai dari penjualan tanpa harus menunggu.

Hal semacam ini terjadi pula dalam kemitraan yang dilakukan oleh PT. BGA dengan Koperasi Mitra Behaum sesuai dengan keterangan yang diberikan oleh Gusti Baseri (68 tahun) seorang pensiunan PNS sebagai masyarakat yang menerima dari pembagian lahan plasma serta anggota koperasi yang menyatakan bahwa: ${ }^{16}$ "Yang tahap pertama ni tabun 2008 semalam ada yg dijual nya tu lalu dipakainya duit sagin naik haji soalnya kan dabulu dapatnya kada seberapa, dapatnya lambat bayar 700 kadang 600 an perbulan dijual nya buku tu keorang lain. Harganya tu sekitar waktu itu 75 juta an per kavling (2 hektar)." (Yang tahap pertama tahun 2008 kemaren ada yang menjualnya lalu dipergunakan buat naik haji uangnya karena dahulu dapatnya tidak seberapa daripembagian (hasil) tersebut sekitar 700 babkan kadang 600 ribu perbulannya kemudian dia jual buku tersebut ke pada pembeli, harga perkavlingnya pada waktu itu sekitar 75 juta an)".

15 Masyakin.

16 Gusti Baseri, Wawancara dengan Anggota Koperasi Mitra Behaum, 30 April 2017. 
Masyarakat yang telah menerima lahan plasma mereka akan mendapatkan buku berwarna merah yang diberikan oleh pihak koperasi sebagai bukti atas kepelikan lahan tersebut dengan identitas masing-masing dari pemiliknya, buku itulah yang digunakan masyarakat yang menerima lahan plasma untuk nantinya dipakai setiap bulannya dalam pengambilan pembagian hasil sawit atau biasa disebut dengan SHK, dari perusahaan kepada koperasi yang kemudian akan dibagikan kepada masyarakat yang telah mendapatkan buku merah tersebut. Apabila ada orang yang menjual lahan nya pada tahap pertama atau kedua maka dia tidak akan mendapatkan lahan plasma pada tahap-tahap berikutnya sebagaimana pemaparan dari Gusti Baseri: ${ }^{17}$

"Kada kawa dapat lagi, dulu kan dapat jatah lahan tu mun kada salah 1,5-2 hektar per KK (Kepala Keluarga) tahap pertama maka tahap kedua inya kada dapat lagi kaya anakku yang pertama kada kawa lagi dapat inya tapi anakku yang kedua kawa dapat soalnya inya sudah terdaftar. (Tidak bisa lagi dapat, dulu jatah lahan kalo tidak salah 1,5-2 hrktar per KK (Kepala Keluarga) tahap pertama maka tahap kedua tidak dapat lagi lahan plasma seperti anaku yang pertama dia tidak bisa dapat lahan plasma lagi tapi anakku yang kedua bisa dapat soalnnya dia sudah terdaftar)".

Dalam mengelola perkebunan sawit tersebut PT. BGA juga bekerja sama dengan beberapa bank yang memberikan pinjaman dana yang nantinya digunakan buat perawatan serta pengelolaan perkebunan sawit. Pinjaman tersebut ada yang diatasnamakan untuk perusahaan tersebut dan ada juga yang diatasnamakan pinjaman anggota koperasi. Lahan plasma sawit yang dikelola oleh perusahaan PT. BGA tersebut setelah buahnya dapat dipanen, maka hasilnya akan dijual oleh perusahaan yang kemudian hasilnya dibagi dengan sistem prosentase yaitu 40\% untuk pembayaran cicilan kredit pada bank, $40 \%$ untuk pengelolaan lahan, dan 20\% diberikan pada pihak koperasi Mitra Behaum yang akan dibagikan kepada anggota (pemilik lahan plasma sawit) yang biasanya disebut dengan SHK, sebagaimana yang diterangkan oleh ketua koperasi Mitra Behaum pak Masyakin ketika ditanyakan dengan pertanyaan sebagai berikut : yang dibagi ke anggota berapa persen dari penghasilan?" $40 \%$ untuk bank, 40\% untuk kebun dan 20\% yang dibagikan keanggotaan, yaitu dari sisa hasil kebun (SHK)". ${ }^{18}$

SHK yang dibagikan setiap bulannya kepada masyarakat akan diumumkan pada masjid-masjid terdekat guna memudahkan warga untuk mengetahui informasi pengambilan SHK, dalam penerimaan SHK setiap bulannya masyarakat yang memiliki lahan plasma sawit mereka tidak mengetahui jelas berapa uang yang dibutuhkan buat pengelolaan perkebunan sawit, dan mereka hanya tau mendapatkan

17 Gusti Baseri.

18 Masyakin, Wawancara dengan Ketua Koperasi Mitra Behaum. 
SHK saja dari pembagian oleh pihak koperasi Mitra Behaum. Masyarakat pun tidak mengetahui letak pasti lahan yang mereka terima, di sebelah mana berbatasan dengan lahan siapa, sesuai dengan pernyataan salah satu anggota Koperasi Mitra Behaum Muhamad Alkab (59 Tahun): ${ }^{19}$

"Naa jadi nang aku bingung ni pemerintah daerah membagi lahan plasma pada masyarakat ni kada tahu letak pastinya dimananya, amunnya orang yang menjual bedabulu setelah sudah berbuah tu mereka kada tabu letak tanah mereka dimana sampai jatuh masa kontraknya dengan perusahan ngitu. (Jadiyang saya bingungkan pemerintah daerah yang membagikan lahan plasma kepada masyarakat ini tidak tahu letak pastinya dimana, kalo ada orang yang menjual tanahnya terlebih dabulu sebelum kontrak mereka habis maka mereka (si pembeli) tidak mengetahui letak tanah mereka dimana sampai selesai masa kontrak dengan perusahaannya)".

Hal semacam ini juga menjadi pertanyaan saya kepada beberapa informan lain seperti kepada Muhammad Noor Alkaini (38 Tahun), Gusti Baseri (68 Tahun), Drs. H. Idham Hadi (64 Tahun), dan masih banyak lagi, yang mana pada intinya jawaban mereka sama yaitu mereka tidak mengetahui lahan pasti sawit plasma milik mereka di sebelah mana dan mereka hanya mendapatkan hasil pembagiannya saja setiap bulan yang disebut dengan SHK tadi. Dan pernyataan dari beberapa informan di atas tersebut juga dipertegas kembali oleh pengurus koperasi Hujairin Hariri selaku wakil ketua Koperasi Mitra Behaum dan Gusti Adi Candra selaku Bendahara Koperasi Mitra Behaum yang menyatakan bahwa memang tidak adanya kejelasan letak pasti dari pembagian lahan plasma sawit yang dibagikan oleh pemerintah daerah.

Pihak koperasi pun tidak ambil alih dalam pembagian SHK. Pengurus koperasi mendapatkan 1,5\% dari 20\% yang diberikan oleh pihak perusahaan, hal semacam ini sesuai dengan pernyataan ketua koperasi Mitra Behaum: ${ }^{20}$

"Jadi klo mau dilihat prinsip yang harus ditembak itu terdapat dalam MoU pasal 10 itu bahwa "perusahaan akan memprioritaskan koperasi terhadap anggota" tetapi perjalannya yang kami rasakan selama ni kemitraan itu sepertinya tidak sejajar mestinya kalo kemitraan itu kan dipandang setara/sejajar".

Dari pernyataan pak Masyakin selaku ketua koperasi Mitra Behaum dapat ditangkap bahwa pihak koperasi sendiri hanya mendapatkan SHU (Sisa Hasil Usaha) dari perkebunan tersebut sebanyak 1,5\% dari $20 \%$ yang diberikan pihak perusahaan yang mana dalam artinya koperasi hanya mendapatkan hasil setiap bulannya tanpa andil alih ikut serta dalam pengelolaan kebun. Seharusnya dalam MoU pasal 10 mereka dipandang setara. Beranjak dari permasalahan tersebut,

19 Muhamad Alkab, Wawancara dengan Anggota Koperasi Mitra Behaum, 2 Mei 2017.

20 Masyakin, Wawancara dengan Ketua Koperasi Mitra Behaum. 
maka perlu diadakan penelitian lebih jauh terkait tinjauan hukum Islam terhadap pembagian hasil dari lahan plasma sawit. Ketidak jelasan kavling (letak tanah) yang berdampak pada ketidakjelasan hasil dari perkebunan inilah yang merupakan bagian yang harus dikaji. Apakah pembagian yang dilakukan oleh koperasi tersebut sudah sesuai dengan hukum Islam. Bagaimana pandangan hukum Islam dengan model kemitraan lahan plasma tersebut, dan hal semacam ini sudah menjadi hal yang telah dilakukan selama bertahun-tahun di daerah Kotawaringin Lama yang mana mereka mayoritas beragama Islam, yang sering kali pula menjadi pertanyaanpertanyaan bagi warga sekitar yang ikut andil alih menjadi anggota koperasi dari lahan plasma sawit tersebut.

Setelah melakukan observasi maka ditemukan 3 subjek yang melakukan perjanjian dalam sistem plasma sawit. Pertama, PT. BGA yang dalam hal ini mereka selaku perusahaan sawit yang mengelola sepenuhkan lahan plasma sawit baik dari pembibitan sampai pemanena yang mana biaya operasionalnya ditangani oleh perusahaan tersebut. Kedua, Koperasi Mitra Behaum selaku badan usaha yang berbentuk hukum yang mana dalam hal ini mewakili masyarakat untuk melakukan kontrak atau kerjasama dalam bentuk kerjasama plasma sawit dengan perushaan, koperasi sangat berperan penting dalam hal ini dan dapat diartikan sebagai jemabatan antara masyarat dan perusahaan tersebut. Ketiga, Masyarakat yang memiliki hak atas lahan plasma sawit yang mana dalam hal ini mereka lah pemilik sah lahan plasma sawit yang digunakan dalam perkebunan tersebut namun letak pasti tiap individu tidak mengetahuinya.

\section{Tinjauan Hukum Islam: Sistem Bagi Hasil dari Lahan Plasma Sawit}

Sebagaimana yang kita ketahui bahwa al-Qur'an adalah kitab suci umat Islam sebagai dasar hukum utama dalam kehidupan di dunia maupun di akhirat. Pembahasan dalam kerjasama mengenai bagi hasil tidak luput pula dengan apa yang tertulis dalam Al-Qur'an, sebagaimana Allah berfirman:

".....dan tolong-menolonglab kamu dalam (mengerjakan) kebajikan dan takwa, dan jangan tolong-menolong dalam berbuat dosa dan pelanggaran. Dan bertakwalah kamu kepada Allah, Sesungguhnya Allah amat berat siksa-Nya"(QS. Al-Maidab: 2). ${ }^{21}$

Dalam ayat tersebut, Allah memerintahkan kepada manusia agar tolongmenolong dalam kebaikan. Wujud tolong-menolong ini tidak hanya dalam bentuk memberikan sesuatu kepada orang yang tidak mampu, tetapi juga bisa dalam bentuk memberikan lapangan pekerjaan kepada mereka. Dalam usaha pertanian maupun perkebunan, tidak semua orang memiliki kemampuan mengolah tanah 21 Departemen Agama RI, Al-Qur'an dan Terjemabnya (Bandung: CV. Daurus Sunnah, 2015). 
dan mengelola lahan perkebunan. Adakalanya seorang pemilik kebun juga tidak dapat mengelola kebunnya karena adanya kesibukan lain sehingga kebunnya itu menjadi terlantar. Sementara di sisi lain, tidak sedikit orang yang memiliki kemampuan bertani tetapi tidak memiliki lahan pertanian, dan apabila diantara mereka tolong-menolong dengan niat kebaikan maka sesungguhnya mereka telah mengerjakan kebajikan.

Akad bagi hasil merupakan akad kerjasama yang bersifat mengikat, walaupun hubungan kerja yang terjalin hanyalah janji biasa, namun kedua belah pihak yang terikat perjanjian kerjasama harus mematuhi aturan yang sudah ditetapkan sebelumnya. ${ }^{22}$ Dalam fiqih muamalah ada 3 akad (perjanjian) yang digunakan dalam bidang perkebunan yaitu: Pertama, musaqoh dalam buku karangan Saleh al-Fauzan musaqob adalah menyerahkan pohon yang telah ditanam dengan sebidang tanah, kepada seorang yang merawatnya di tanah tersebut (seperti menyiram dan sebagainya hingga berbuah) lalu pekerja mendapatkan sebagian yang telah disepakati dari buah yang dihasilkan, sedangkan sisanya adalah untuk pemiliknya. ${ }^{23}$ Kedua, muzara'ah menurut bahasa berarti tharh al-zur'ah (melempar tanaman). ${ }^{24}$ Namun pendapat dari beberapa madzhab dan fuqaha maka dapat disimpulkan bahwa muzara'ah merupakan kerjasama antara pemilik tanah dan penggarap tanah sedangkan benih (bibit) tanaman berasal dari pemilik tanah. Ketiga, mukhabrah menurut Syafi'iyah adalah mengelola tanah di atas sesuatu yang dihasilkannya dan benihnya berasal dari pengelola. Adapun muzara'ah sama seperti mukhabarah hanya saja benihnya berasal dari pemilik tanah. ${ }^{25}$

Hukum mukhabarah sama seperti muzara'ah dan musaqoh yaitu mubah atau boleh dan seseorang dapat melakukannya untuk dapat memberi dan mendapat manfaatnya dari kerjasama muzara'ah dan mukhabarah ini. Setelah kita ketahui hukum mukhabarah itu dibolehkan maka ada rukun yang dan syaratnya agar mukhabarah terlaksana sesuai dengan syariat yang dibenarkan didalam Islam.

Rukun mukhabarah menurut Hanafiyah adalah ijab dan kabul, yaitu berupa pernyataan pemilik tanah, "Saya serabkan tanah ini kepada anda untuk daigarap dengan imbalan separuh dari hasilnya" dan pernyataan penggarap "saya terima atau saya setuju". Sedangkan menurut jumhur ulama, sebagaimana dalam akadakad yang lain, rukun mukhabarah ada empat, yaitu: Pertama, pemilik tanah, yaitu orangyang memiliki lahan tetapi tidak memiliki kemapuan atau kesempatan dalam mengelola lahannya. Kedua, petani penggarap, yaitu orang yang memiliki

22 Hasan, Berbagai Macam Transaksi dalam Islam..., h. 271.

23 Saleh Al-Fauzan, Fiqh Sehari-hari (Jakarta: Gema Insani Press, 2005). h. 476.

24 Abdurrahman al-Jaziri, Fiqh Ala Madzahib al-Arba'ah (Beirut: Dar al-Qalam, 1969). h. 1.

25 Rachmat Syafe'i, Fiqh Muamalah (Bandung: Pustaka Setia, 2001). h. 205. 
kemampuan untuk mengelola lahan dan berkesempatan tetapi tidak memilik lahan. Ketiga, objek mukhabarah, yaitu antara manfaat lahan dan hasil kerja pengelola. Keempat, ijab dan kabul. ${ }^{26}$

Muzara'ah dan mukhabarah dalam KHES dijadikan dalam 1 BAB yaitu pada BAB IX bagian pertama Pasal 255 mengenai rukunnya ialah: Pemilik lahan, penggarap, lahan yang digarap, dan akad. Serta mengenai syaratnya terdapat dalam pasal 256-261. Kemudian penjelasan batalnya akad dijelaskan dalam pasal 262$262 .{ }^{27}$ Berpatokan pada 4 rukun diatas maka dapat dijabarkan hasil observasi yang dikaitkan dengan kajian teori menjadi sebagai berikut:

Menurut jumhur ulama rukun mukhabarah ada empat sebagaimana akad-akad yang lain, yaitu: Pertama, pemilik tanah yaitu masyarakat yang berada di empat daerah yaitu: Kelurahan Kotawarungin Hilir (Kohil), Kelurahan Kotawaringin Hulu (Kohul), Desa Sakabulin, dan Desa Lalang. Yang mana mendapatkan jatah lahan plasma dari pemerintah daerah tersebut. Kedua, penggarap/pengelola yaitu PT. Bumitama Gunajaya Abadi (BGA) yang menjadi pengelola penuh atas perkebunan sawit pada lahan plasma di empat daerah tersebut. Ketiga, objek yaitu pada perkebunan kelapa sawit dari lahan plasma sawit. Keempat, ijab dan kabul yang dituangkan dalam sebuah perjanjian berupa $\mathrm{MoU}$ antara perusahaan dan koperasi, kemudian dari koperasi kepada masyarakat perjanjiannya berupa buku merah yang berguna sabagai bukti kepemilikan bagi masyarakat pemilik lahan plasma.Maka dari sudah sesuai dengan yang disyariatkan oleh Islam, yakni adanya 4 kompenan yang telah dipenuhi baik berupa akad, pemilik lahan, penggarap, dan objek nya.

Beranjak dari rukun dan dasar hukum mengenai mukhabarah di atas maka poin selanjutnya dalam pembahasan ini yaitu berupa syarat-syarat dari mukhabarah itu sendiri. Syarat-syarat mukhabarah meliputi: Pertama, syarat aqid (pelaku), secara umum ada dua syarat yang diberlakukan untuk aqid yaitu: Aqid harus berakal (mumayyiz). Dengan demikian, tidak sah akad yang dilakukan oleh orang gila, atau anak yang belum mumayiz, karena akal merupakan syarat kecakapan (ahliyah) untuk melakukan tasarruf. Adapun baligh tidak menjadi syarat dibolehkan mukhabarah. Berikuutnya aqid tidak murtad, menurut pendapat Imam Abu Hanifah dalam buku karangan Ali Hasan, hal tersebut dikarenakan menurut Imam Abu Hanifah, tasarruf orang yang murtad hukumnya ditangguhkan (mauquf) sedangkan menurut Abu Yusuf dan Muhammad bin Hasan, akad mukharabah dari orang yang murtad hukumnya dibolehkan. Sedangkan jika yang murtad dari

26 Abdul Rahman Ghazali, Ghufran Ihsan, dan Sapiudin Shidiq, Fiqh Muamalat (Jakarta: Kencana, 2010). 27 Pusat Pengkajian Hukum Islam dan Masyaratakat Madani, Kompilasi Hukum Ekonomi Syariah Edisi Revisi (Jakarta: Kencana, 2009). h. 76-79. 
kalangan wanita maka semua ulama dari kalangan mazhab Hanafi memperbolehkan melakukan akad muzara'a ${ }^{28}$. Kedua, syarat tanaman yaitu syarat yang berlaku untuk tanaman adalah harus jelas dan menghasilkan. Dalam hal ini harus dijelaskan apa yang akan ditanam. Namun diilihat dari segi istibsan, menjelaskan sesuatu yang akan ditanam tidak menjadi syarat mukhabarah karena apa yang akan ditanam diserahkan sepenuhnya kepada penggarap. Ketiga, syarat hasil tanaman yaitu hasil tanaman harus dijelaskan (persentasenya) dalam perjanjian, hasil tanaman harus dimiliki bersama oleh para yang melakukan akad. Apabila disyaratkan hasilnya untuk salah satu pihak maka menjadi batal, pembagian hasil tanaman harus ditentukan kadarnya (nisbah-nya), seperti separuh, sepertiga, seperempat, dan sebagainya, hasil tanaman harus berupa bagian yang belum dibagi di antara orang-orang yang melakukan akad. Keempat, syarat tanah yang akan ditanami yaitu (a) Tanah harus layak untuk ditanami, menurut adat kebiasaan dikalangan petani, dalam artian bisa diolah dan menghasilkan. Sebab, ada tanaman yang tidak cocok ditanami pada daerah tertentu. (b) Tanah yang akan digarap harus diketahui dengan jelas, supaya tidak menimbulkan perselisihan antara para pihak yang melakukan akad. (c) Tanah tersebut harus sepenuhnya kepada penggarap, sehingga ia mempunyai kebebasan untuk menggarapnya dan pemilik lahan tidak boleh ikut campur tanganuntuk mengelolanya. ${ }^{29}$ Kelima, syarat objek akad yaitu objek akad dalam mukhabarah harus sesuai dengan dilaksanakannya akad, baik menurutn syara maupun urf(adat). Keenam, syarat masa mukhabarah yang mana masa berlakunya akad mukhabarah harus jelas dan ditentukan atau diketahui, misalnya satu tahun atau dua tahun. Apabila masanya tidak ditentukan (tidak jelas) maka akad mukhabarah tidak sah. ${ }^{30}$

Dari ke 6 syarat diatas, syarat tersebut telah sesuai dengan apa yang terjadi dilapangan namun terdapat syarat pada mukhabar yang dapat menimbulkan kurang sempurnanya akad. Yaitu syarat poin ke empat mengenai tanah yang akan ditanami dapat digaris bawahi kalimat yang membahas mengenai "Tanah yang akan digarap harus diketahui dengan jelas, supaya tidak menimbulkan perselisihan antara para pihak yang melakukan akad". Hal ini lah yang menyebabkan kurang sempurnanya syariat mukhabarah karena menurut hasil observasi yang didapat bahwa masyarakat yang mendapatkan lahan plasma tidak mengetahui letak pasti lahan yang mereka dapatkan sesuai dengan pernyataan salah beberapa informan sebagaimana yang dijelaskan oleh penulis diatas. Pada intinya jawaban mereka sama yaitu mereka tidak mengetahui lahan pasti sawit plasma milik mereka disebelah

28 Za'tari Alauddin, Fiqh Mu'amalat Al-Maliyah Al-Muqaran (Beirut: Dar Al-Ashma, t.t.).h. 474.

29 Hasan, Berbagai Macam Transaksi dalam Islam..., h. 277-278.

30 Ahmad Wardi Muslich, Figh Muamalat (Jakarta: Amzah, 2010). h. 398. 
mana dan mereka hanya mendapatkan hasil pembagiannya saja setiap bulan yang disebut dengan SHK. Kemudian dalam prakteknya lahan plasma banyak diperjual belikan oleh beberapa masyarakat diempat daerah tersebut. Padahal tanah tersebut masih dalam masa penggarapan kebun plasma sawit yang mana belum ada kepastian letak sampai beberapa tahun kedepan. Hal ini juga menyebabkan berakhirnya mukhabarah menurut ulama Hanafiyah yaitu adanya uzur terkait tanah garapan yang dijual, misalnya untuk membayar hutang. ${ }^{31}$

Ditinjau dari segi bagi hasilnya sudah sesuai dengan mukhabarah yaitu adanya bagian-bagian tetentu seperti seperdua, sepertiga, dan lain-lain. Yang dituangkan dalam prosentase sesuai pernyataan dari ketua koperasi: "40\% untuk bank, 40\% untuk kebun dan 20\% yan dibagikan keanggotaan, yaitu dari sisa hasil kebun (SHK)". ${ }^{2}$ Bagi hasil sebagaimana yang ditentukan oleh pihak koperasi dan perusahaan telah adanya kejelasan pembagian yaitu berupa prosentase yang hal tersebut telah sesuai (tidak gharar) dengan syarat mukhabarh itu sendiri. Namun dari segi syarat mengenai tanah yang akan ditanami tidak sesuai dengan mukhabarah. Sehingga menimbulkan kurang sempurnanya akad dalam hal ini.

Setelah dilakukan observasi maka ketiga akad di atas bukanlah bentuk akad yang sesuai dalam penelitian ini namun bentuk yang mendekati adalah mukhabarah karena pengertian dari mukhabarah sendiri secara singkatnya adalah pengelola tanah yang bekerjasama dengan pemilik lahan namun biaya operasionalnya berasal dari pengelola. Apabila dikaitkan kembali dengan hasil observasi maka jelas bahwa pengelola (PT. Bumitama Gunajaya Abadi) yang menanggung semua biaya dari pembibitan samapai pemanenan, yang mana masyarakat selaku pemilik lahan plasma sawit tidak tahu menahu dalam hal ini. Namun perlu digarisbawahi adanya tugas Koperasi Mitra Behaum sebagai suatu badan usaha yang mewakili masyarakat dalam hal ini. Maka dari paparan di atas mempunyai kecocokan. Namun, dari segi subjek yang melakukan akad dalam mukhabarah hanyalah antara pengelola dan pemilik lahan saja, sedangkan dalam penelitian kali ini ada subjek tambahan yaitu pihak koperasi sebagai jembatan antara kedua objek tersebut sehingga belum tepat kiranya dikatakan dalam bentuk kerjasama akad mukhabarah. Tapi kasus sebagaimana yang penulis jabarkan erat kaitannya dengan akad mukahabarah tersebut.

\section{Simpulan}

Bentuk perjanjian bagi hasil seperti apa yang diterapkan dalam studi kasus

31 Rachmat Syafe'i, Fiqh Muamalah..., h. 211.

32 Masyakin, Wawancara dengan Ketua Koperasi Mitra Behaum. 
pada penelitian ini, yaitu ada 3 pihak atau subjek dalam perjanjian dalam penelitian kali ini adalah PT. Bumitama Gunajaya Abadi selaku pengelola kebun plasma, Koperasi Mitra Behaum yang menjembatani antara masyarakat dan perusahaan terkait pembagian hasil atau disebut SHK( Sisa Hasil Kebun) setiap bulannya atau bisa diartikan yang mewakili masyarakat dalam hal kontak kepada perusahaan, dan masyarakat di 4 daerah yaitu Kel. Kotawaringin Hulur, Kel. Kotawaringin Hilir, Desa Sakabulin, Desa Lalang selaku pemilik lahan plasma sawit. Menggabungkan sumber data primer maupun sekunder maka dapat disimpulkan perjanjian (akad) yang digunakan dalam penelitian kali ini adalah condong pada akad mukhabarah yaitu pemilik lahan yang mana tanahnya tersebut dikelola oleh pengelola untuk digunakan dalam sektor pertanian/perkebunan yang mana modal dari penanaman buah sampai pemetikan ditanggung oleh pihak pengelola yaitu PT. Bumitama Gunajaya Abadi. Namun, dari segi subjek yang melakukan akad dalam mukhabarah hanyalah antara pengelola dan pemilik lahan saja, sedangkan dalam penelitian kali ini ada subjek tambahan yaitu pihak koperasi sebagai jembatan antara kedua objek tersebut sehingga belum tepat kiranya dikatakan dalam bentuk kerjasama akad mukhabarah. Tapi kasus sebagaimana yang penulis jabarkan erat kaitannya dengan akad mukahabarah tersebut.

Dalam KHES yaitu pada BAB IX bagian pertama Pasal 255 mengenai rukun ialah: pemilik lahan, penggarap, lahan yang digarap, dan akad. Dari segi rukun maka sudah sesuai baik ditinjau dari KHES (Kompilasi Hukum Ekonomi Syariah) maupun dari hukum Islam. Namun, dari segi syarat nya belum memenuhi yaitu terkait tanah yang akan ditanami, yaitu tanah yang akan digarap harus diketahui dengan jelas, supaya tidak menimbulkan perselisihan antara para pihak yang melakukan akad. Hal ini lah yang menyebabkan kurang sempurnanya syarat terebut karena menurut hasil observasi yang didapat bahwa masyarakat yang mendapatkan lahan plasma tidak mengetahui letak pastinya. Kemudian pada bagi hasil sebagaimana yang ditentukan oleh pihak koperasi Mitra Behaum dan perusahaan PT. Bumitama Gunajaya Abadi telah adanya kejelasan pembagian yaitu berupa porsentase yang hal tersebut telah sesuai (tidak gharar). Yaitu berupa 20\% dari SHK (Sisa Hasil Kebun) setiap bulannya.

\section{Daftar Pustaka}

\section{Buku}

Abdul Rahman Ghazali, Ghufran Ihsan, dan Sapiudin Shidiq. Fiqh Muamalat. Jakarta: Kencana, 2010. 
Abdurrahman al-Jaziri. Fiqh Ala Madzabib al-Arba'ah. Beirut: Dar al-Qalam, 1969. Ahmad Wardi Muslich. Figh Muamalat. Jakarta: Amzah, 2010.

Alauddin, Zảtari. Fiqh Mu'amalat Al-Maliyah Al-Muqaran. Beirut: Dar Al-Ashma, t.t.

Amiruddin, dan Zainal Asikin. Pengantar Metode Penelitian Hukum. Jakarta: PT. Raja Grafindo Persada, 2008.

Andi Prastowo. Metode Penelitian Kualitatif dalam PerspektifRancangan Penelitian. Yogyakarta: Ar-Ruzz Media, 2011.

Departemen Agama RI. Al-Quran dan Terjemahnya. Bandung: CV. Daurus Sunnah, 2015.

Gusti Baseri. Wawancara dengan Anggota Koperasi Mitra Behaum, 30 April 2017.

Hasan, M. Ali. Berbagai Macam Transaksi dalam Islam. Jakarta: PT. Raja Grafindo Persada, 2003.

Lexy J. Moeleong. Metode Penelitian Kualitatif. Bandung: Remaja Rosdakarya, 2013.

Masyakin. Wawancara dengan Ketua Koperasi Mitra Behaum, 29 April 2017.

Muhamad Alkab. Wawancara dengan Anggota Koperasi Mitra Behaum, 2 Mei 2017.

Peter Mahmud Marzuki. Penelitian Hukum. Jakarta: Kencana, 2011.

Pusat Pengkajian Hukum Islam dan Masyaratakat Madani. Kompilasi Hukum Ekonomi Syariah Edisi Revisi. Jakarta: Kencana, 2009.

Rachmat Syafe'i. Fiqh Muamalah. Bandung: Pustaka Setia, 2001.

Rahmat Indra Irawan. "Perjanjian Bagi Hasil Antara Buruh Sawit Dan Pemilik Kebun Sawit (Di Desa Muara Jaya Sp3 Kecamatan Kepenuhan Hulu Kabupaten Rokan Hulu Provinsi Riau Perspektif Kompilasi Hukum Ekonomi Syariah)." Skripsi, Universitas Islam Negeri Maulana Malik Ibrahim, 2016.

Rudianto Salmon Sinaga. "Masalah Hukum Dalam Perjanjian Kemitraan Inti Plasma Perkebunan Kelapa Sawit (Studi Kasus Pada PT. SHM dengan 
Koperasi PGH) dan Tindakan Notaris dalam Menghadapi Perjanjian Kemitraan Inti Plasma Dalam Perkebunan Kelapa Sawit." Tesis, Universitas Indonesia, 2011.

Saleh Al-Fauzan. Figh Sehari-hari. Jakarta: Gema Insani Press, 2005.

Soerjono Soekanto. Pengantar Penelitian Hukum. Jakarta: UI-Press, 2012.

Suharsimi Arikunto. Prosedur Penelitian Suatu Pendekatan Praktek. Jakarta: Rineka Cipta, 2002.

Sumadi Suyabrata. Metode Penelitian. Jakarta: PT. Raja Grafindo Persada, 2003.

\section{Artikel}

Almasdi Syahza. "Pemberdayaan Ekonomi Masyarakat Pedesaan Melalui Pengembangan Industri Hilir Berbasis Kelapa Sawit Di Daerah Riau.” Jurnal Sosiobumaniora, No. 3, Vol. 6 (2004).

Iglesias Asik. "Program Plasma Perkebunan Kelapa Sawit PT. Rimba Rayatama Jaya Dalam Pola Kemitraaan Masyrakat Di Kampung Besiq Kecamatan Damai Kabupaten Kutai Barat." eJournal Ilmu Pemerintahan, No. 2, Vol. 5 (2017). 